\title{
VIDEO MOVING SURVEILLANCE YANG TERINTEGRASI YOUTUBE MENGGUNAKAN RASPBERRY PI 3
}

\author{
Pipit Utami ${ }^{1}$, Abdul Aziz Sidiq Tri Putra ${ }^{2}$, Djoko Santoso ${ }^{3}$, Nuryake Fajaryati ${ }^{4}$, \\ Bonita Destiana $^{5}$, Mohd Erfy Ismail ${ }^{6}$ \\ 1,2,3,4,5 Universitas Negeri Yogyakarta, ${ }^{6}$ Universiti Tun Hussein Onn Malaysia \\ E-mail: pipitutami@uny.ac.id
}

\begin{abstract}
Static CCTV facilities in class need to be optimized in classroom learning, especially in recording learning activities as implementation of learning in the 21st century and strategic steps to face the Industrial Revolution 4.0. Educators need to play a role in utilizing CCTV in learning. This article presents the development of YouTube Integrated Video Moving Surveillance devices using Raspberry Pi 3. The development stages consist of analysis, design, development and evaluation. The analysis shows that: (1) the limitations of CCTV motion are followed up with the addition of motor servo; (2) limited access to video recording data is followed up by sending in real time using YouTube; and (3) controlling the system performance of the device using Raspberry Pi 3 model B. The evaluation results show that all electronic measurement parameters are in accordance with the success target and the functional test shows that the device can function to record classroom learning activities that can be monitored in real time via YouTube with good quality (average delay is 22,89s). The results of the development of this device are expected to be an alternative use of technology in learning, especially in the supervision and assessment of student learning activities.
\end{abstract}

Keywords: CCTV, surveillance in classroom, YouTube, Raspberry Pi 3, $21^{\text {st }}$ century learning, Industrial Revolution 4.0.

\begin{abstract}
ABSTRAK
Fasilitas CCTV statis di kelas perlu dioptimalkan dalam pembelajaran di kelas, khususnya dalam merekam aktivitas pembelajaran sebagai implementasi pembelajaran di abad 21 dan langkah strategis menghadapi Revolusi Industri 4.0. Pendidik perlu berperan memanfaatkan CCTV dalam pembelajaran. Artikel ini menyajikan pengembangan perangkat Video Moving Surveillance yang Terintegrasi YouTube menggunakan Raspberry Pi 3. Tahapan pengembangan terdiri atas analisis, desain, pengembangan dan evaluasi. Analisis menunjukkan bahwa: (1) keterbatasan gerak CCTV ditindaklanjuti dengan penambahan motor; (2) keterbatasan akses data perekaman video ditindaklanjuti dengan pengiriman secara real time dengan memanfaatkan YouTube; dan (3) pengendali sistem kinerja perangkat menggunakan Raspberry Pi 3 model B. Hasil evaluasi menunjukkan bahwa semua parameter pengukuran elektronika sesuai dengan target keberhasilan dan uji fungsionalitas menunjukkan bahwa perangkat dapat berfungsi untuk merekam aktivitas pembelajaran di kelas yang dapat dipantau secara real time melalui YouTube dengan kualitas yang baik (rata-rata delay sebesar 22,89s). Hasil pengembangan perangkat ini diharapkan dapat menjadi alternatif pemanfaatan teknologi dalam pembelajaran khususnya dalam pengawasan dan penilaian aktivitas belajar siswa.
\end{abstract}

Kata kunci: CCTV, pengawasan pembelajaran di kelas, YouTube, Raspberry Pi 3, pembelajaran abad 21, Revolusi Industri 4.0.

\section{PENDAHULUAN}

Peran teknologi dalam pembelajaran di abad 21 dan menghadapi revolusi industri 4.0 perlu diterapkan oleh para pendidik. Glenn Starlin menyarankan penggunaan teknologi dalam hal ini berupa CCTV untuk digunakan oleh pendidik mengobservasi prosedur pembelajaran di kelas yang memungkinkan pendidik untuk mendiskusikan permasalahan yang muncul tanpa mengganggu kegiatan di kelas ${ }^{(1)}$. Penggunaan video dapat digunakan untuk memantau para peserta didik dan melakukan refleksi pengelolaan pembelajaran 
oleh pendidik ${ }^{(2)}$. Refleksi tersebut untuk menekan kesulitan-kesulitan pendidik dalam mengelola pembelajaran dikelas ${ }^{(2)}$. Selain itu, melalui video ${ }^{(3)}$ dan atau $\mathrm{CCTV}^{(4)}$ juga dapat digunakan untuk menilai keefektifan pendidik dalam pembelajaran di kelas. Terlebih lagi penggunaan video jarak jauh untuk mengobservasi pembelajaran dikelas lebih dipilih oleh calon pendidik karena akan menunjukkan pengalaman observasi ditempat yang lebih bermakna dan efektif ${ }^{(5)}$. Penggunaan CCTV lainnya adalah untuk pengawasan Ujian Nasional Berbasis Komputer (UNBK), dimana selain pengawas berada didalam ruangan ${ }^{(6 ; 7 ; 8)}$, CCTV juga digunakan. Penggunaan CCTV pada pelaksanaan UNBK merupakan bentuk kreativitas yang sangat bagus, membuktikan semangat kejujuran dalam pelaksanaan UNBK ${ }^{(6)}$, dapat meningkatkan integritas peserta didik (7). Perekaman aktivitas pembelajaran berbasis video dapat digunakan untuk melakukan refleksi pembelajaran baik untuk mengobservasi peserta didik maupun pendidik demi pembelajaran yang lebih efektif. Dalam dunia digital, video dapat diakses secara online melai YouTube.

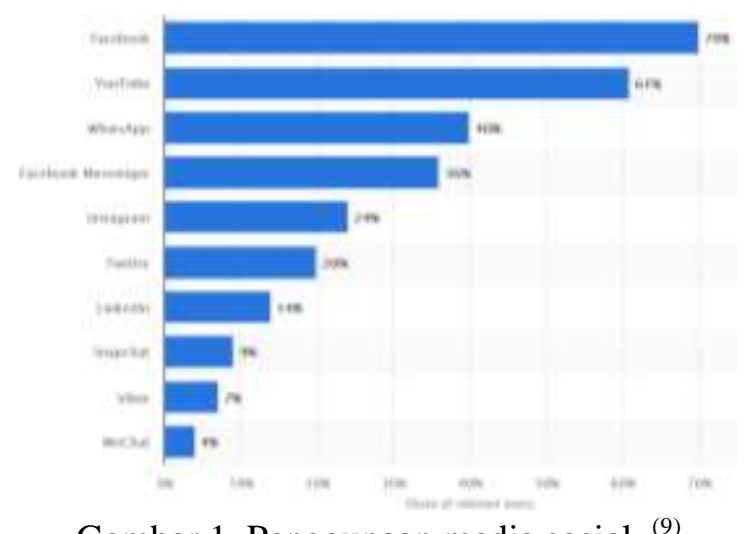

Gambar 1. Penggunaan media sosial ${ }^{(9)}$

YouTube merupakan tujuan akses di dunia maya nomor dua ${ }^{(9)}$. YouTube merupakan media sosial berisi video yang menghilangkan hambatan teknis penyebaran video secara online, sederhana dan dengan tampilan terintegrasi yang membuat pengguna dapat mengunggah, mempublikasi dan melihat video streaming tanpa pengetahuan teknis yang tinggi. YouTube telah berkembang menjadi layanan berbagi video daring terbesar dan paling banyak dikunjungi. Sebagai tambahan, penggunaan YouTube dalam pendidikan semakin diminati ${ }^{(10)}$. Keunggulan YouTube diantaranya adalah: (1) akses yang begitu mudah bisa dari manapun; (2) internet yang relative tidak terlalu mahal; (3) video menceritakan lebih detil dan mudah dipahami; dan (4) youtube lebih aplikatif dan inspiratif. YouTube mengakomodasi kebutuhan pengguna yang tidak mau lagi menghabiskan waktu untuk membaca dalam waktu lama, tetapi memilih memahami sesuatu dari apa yang dilihat dan didengar melalui YouTube ${ }^{(11)}$. Pemahaman melalui aktivitas melihat dan mendengar konten YouTube ini dapat dimanfaatkan untuk pendidikan.

Akses video online melalui Youtube didunia pendidikan sudah sering digunakan ${ }^{(12}$; 13; 14), salah satunya melalui penerapan flipped classroom atau inverted classroom, dimana video diakses online melalui YouTube. Flipped classroom berusaha merubah model pembelajaran sebelumnya, yaitu pemberian materi didalam kelas dan pengerjaan tugas (pekerjaan rumah) di luar kelas menjadi pembelajaran melalui video yang dikemas lebih interaktif dan menarik di luar kelas dan mengerjakan tugas di dalam kelas $(15 ; 16)$. Aktivitas pengerjaan tugas tersebut, apabila terekam dalam bentuk video dan dapat diakses melalui YouTube dapat juga menjadi sumber pembelajaran, misalnya saja aktivitas praktikum yang memperlihatkan unjuk kerja teknis. Melalui youtube, pengguna dapat mengakses online baik real time ataupun dengan mengunduhnya yang dapat dibuka berkali-kali, sehingga dapat ditampilkan secara offline. YouTube sebagai teknologi mutakhir dari ICT dapat digunakan dalam pembelajaran untuk melakukan refleksi (17). Artikel ini menyajikan salah satu peranan YouTube dalam pendidikan, yaitu refleksi pembelajaran, khususnya untuk memonitoring pembelajaran dikelas saat pendidik tidak berada dikelas dalam waktu bersamaan, dimana terdapat akses melalui YouTube secara real time yang 
menampilkan aktivitas pembelajaran. Monitoring tersebut dapat bermanfaat untuk pendidik dalam mengamati aktivitas belajar peserta didik dan sekaligus dapat bermanfaat untuk peserta didik untuk melihat ulang aktivitas belajarnya misalnya terkait pembelajaran praktik. Monitoring aktivitas siswa di kelas dapat dilakukan dengan melakukan pengintegrasian perangkat kamera untuk merekam video, motor sebagai penggerak kamera dan sebuah pengendali. Pengendali yang dapat digunakan adalah mini computer Raspberry Pi 3 seperti Gambar 2 berikut ini.

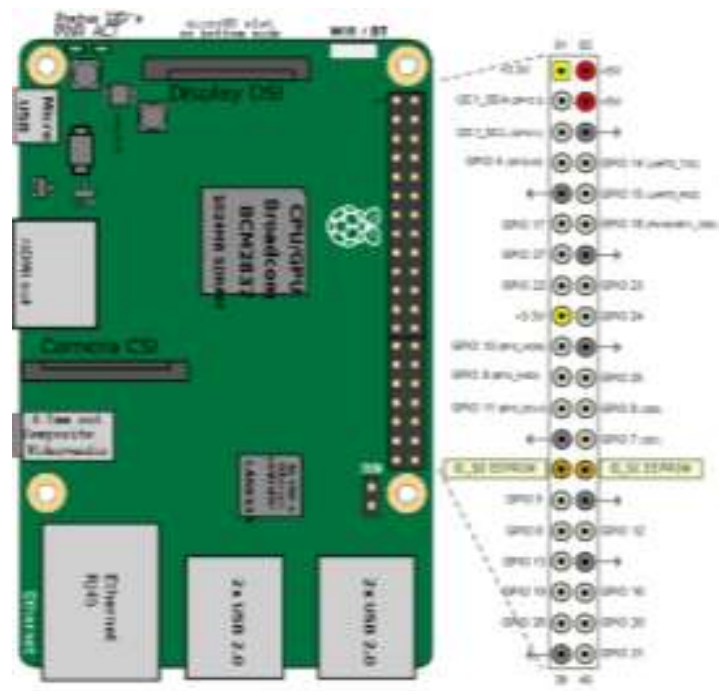

Gambar 2. Spesifikasi dan port Raspberry Pi 3 model $\mathrm{B}^{(18)}$

Spesifikasi teknis dari Raspberry Pi 3 diantaranya adalah: (1) prosesor menggunakan Broadcom BCM2837 chipset, 1.2GHz Quad Core Arm Cortex-A53 64bit; (2) $802.11 \mathrm{~b} / \mathrm{g} / \mathrm{n}$ wireless LAN dan Bluetooth 4.1; (3) GPU berupa dual core video core IV multimedia coprocessor yang menyediakan Open GL ES 2.0, hardware-accelerated open VG and 1080p 30 H.264 high-profile decode, capable of $1 \mathrm{Gpixel} / \mathrm{s}$, 1,5Gtexel/s or 24GFLOPs with texture filtering and DMA infrastructure; (4) memori berkapasitas 1GB LPDDR2; (5) sistem operasi, boots from Micro SD Card bekerja di Linux atau Windows 10; (6) dimensi berukuran 85 x 56 x $17 \mathrm{~mm}$; (7) power menggunakan micro USB socket $5 \mathrm{~V}$ 2,5 A; dan (8) konektor terdiri atas: (a) 10/100 BaseT Ethernet socket; (b) video output berupa HDMI dan composite RCA; (c) audio output 3,5mm jack; (d) 40 pin konektor GPIO; (e) port CSI Camera untuk koneksi dengan Raspberry Pi camera; (f) port DSI display untuk mengkoneksikan tampilan layar sentuh; dan (g) slot memory card untuk memuat sistem operasi dan menyimpan data $(19 ; 20)$. GPU (Graphics Processing Unit) perangkat ini dapat menampilkan video berkualitas BluRay ketika dipasang ke HDTV, menggunakan prosesor utama yang lebih baik dari tipe sebelumnya, memiliki konektivitas Bluetooth low energy dan Wi-Fi on board, serta perangkat USB eksternal yang lebih dayanya lebih kuat. Port USB pada Raspberry Pi 3 memungkinkan konektivitas untuk mouse, keyboard atau perangkat lain yang dibutuhkan dengan konektivitas berupa port USB. Kinerja Raspberry Pi3 lebih cepat seitar 50-60\% daripada Raspberry Pi $2^{(20)}$.

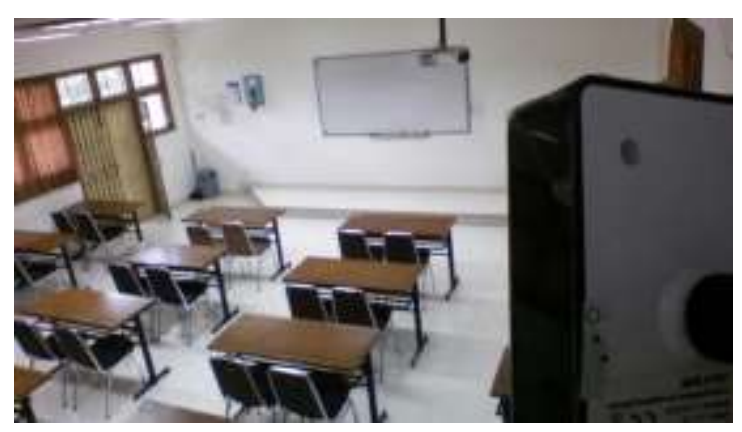

Gambar 3. CCTV pada salah satu ruangan kelas JPTEI

Gambar 3 memperlihatkan kamera pengawas (CCTV) terpasang di dalam kelas Jurusan Pendidikan Teknik Elektronika dan Informatika (JPTEI). Namun demikian, penggunaan kamera pengawas tersebut tidak memiliki dampak yang signifikan dalam pembelajaran. Baik pendidik maupun pengelola jurusan belum memanfaatkan penggunaan CCTV tersebut secara optimal, bahkan aktivitas data perekaman juga tidak terdata dengan baik oleh administrator di tingkat Fakultas. Dilain pihak, keterbatasan pengawasan pendidik menghadapi jumlah mahasiswa yang cukup banyak di kelas 
merupakan permasalahan klasik yang terjadi. Aktivitas belajar siswa tidak terekam sepenuhnya dalam pengawasan pendidik. Sebagai tambahan, pendidik juga tidak dapat melakukan konfirmasi pengamatan aktivitas belajar siswa melalui CCTV yang telah terpasang di dalam kelas. Dilain pihak, peserta didik juga tidak dapat melihat kembali aktivitas belajarnya sebagai refleksi pembelajaran sebagai upaya melakukan recall pengalaman belajar yang telah dilakukan. CCTV yang ada saat ini merupakan CCTV statis, sehingga apabila digunakan maka memiliki jangkauan perekaman yang terbatas. Oleh karena itu dibutuhkan suatu penggerak tambahan, agar perangkat yang ada (CCTV) tersebut tetap dapat dioptimalkan penggunaannya.

Pendidik perlu berperan aktif dalam pembelajaran abad 21 dan menghadapi revolusi industri 4.0. Keterampilan abad 21 terdiri atas learning and innovation skills, digital literacy skills dan career and life skills (21). Apabila digital literacy skills diturunkan salah satu bagiannya adalah media literacy skills, yaitu mampu menganalisis dan menghasilkan media (21). Implementasi keterampilan tersebut oleh pendidik abad 21 perlu dilakukan. Dalam hal ini adalah pengembangan perangkat berbasis teknologi yang diterapkan dalam pembelajaran. Dengan demikian pendidik dapat memberikan contoh secara langsung kepada peserta didik terkait penerapan kepemilikan keterampilan abad 21 . Dua dari lima elemen penting Menristekdikti untuk mendorong daya saing bangsa di era Revolusi Industri 4.0, yaitu: persiapan sistem pembelajaran yang lebih inovatif di perguruan tinggi dengan memanfaatkan teknologi informasi dan rekonstruksi kebijakan kelembagaan pendidikan tinggi yang adaptif dan responsive terhadap revolusi industry 4.0 . salah satunya dengan sistem perkuliahan distance learning ${ }^{(22)}$. Terkait hal tersebut pengembangan perangkat Video Moving Surveillance yang Terintegrasi YouTube menggunakan Raspberry Pi 3 telah menjawab kedua elemen tersebut, yaitu pembelajaran yang lebih inovatif dan perangkat tersebut juga dapat diterapkan untuk sistem perkuliahan distance learning.

Artikel ini menyajikan pengembangan Video Moving Surveillance yang Terintegrasi YouTube menggunakan Raspberry Pi 3. Video Moving Surveillance yang dimaksud adalah pengawasan dengan video bergerak untuk merekam aktivitas di kelas oleh peserta didik. Akses pengawasan melalui akun YouTube yang diakses oleh Pendidik. Pendidik tidak menggantikan tugasnya dengan kamera perekam video, tapi menggunakan kamera tersebut untuk membantu melakukan pengamatan secara mendalam sekaligus memberi kesempatan peserta didik untuk dapat bereksplorasi. Raspbery Pi 3 digunakan sebagai pengendali gerakan kamera perekam video sekaligus mengirimkan hasil perekaman ke YouTube.

\section{METODE}

Permasalahan: Pemanfaatan CCTV statis terbatas pada gerak dan akses data

Kajian: CCTV dapat dimanfaatkan untuk refleksi pembelajaran; akses YouTube mudah dan dapat menampilkan kondisi secara real time; Pendidik perlu mengambil peran pada pembelajaran abad 21 dan menghadapi Revolusi Industri 4.0

Analisis kebutuhan terkait analisis tujuan, penyelesaian masalah dan produk dari pengembangan perangkat

Desain: identifikasi kebutuhan komponen elektronika, rancangan blok diagram, software dan kinerja perangkat

Pengembangan: rangkaian hardware, pemrograman, packaging, pembuatan manual book

Evaluasi: uji kinerja melalui pengukuran parameter elektronika dan uji fungsionalitas

Perbaikan hasil evaluasi. Hasil perangkat Video Moving Surveillance yang

Terintegrasi YouTube menggunakan

Raspberry Pi 3 berfungsi sesuai tujuan yang ditetapkan.

Gambar 4. Tahapan pengembangan 
Gambar 4 menunjukkan hubungan permasalahan penelitian, tahapan pengembangan dan hasil yang dicapai. Adanya fasilitas CCTV di ruangan-ruangan kelas Jurusan Pendidikan Teknik Elektronika dan Informatika perlu dioptimalkan penggunaannya dalam pembelajaran di kelas, khususnya dalam merekam aktivitas pembelajaran. Hal tersebut sesuai sebagai implementasi pembelajaran di abad 21 yaitu penerapan digital literacy skills dan sekaligus langkah strategis untuk menghadapi Revolusi Industri 4.0 yaitu pembelajaran inovatif dan sistem perkuliahan distance learning. CCTV yang terpasang memiliki keterbatasan berupa gerak statis dan akses data perekaman yang terbatas oleh administrator di tingkat Fakultas. Oleh karena itu merupakan tugas pendidik di abad 21 yaitu memanfaatkan teknologi dalam pembelajaran, untuk mengembangkan perangkat yang merekam sekaligus mengawasi aktivitas pembelajaran. perangkat yang dimaksud adalah Video Moving Surveillance yang Terintegrasi YouTube menggunakan Raspberry Pi 3.

Metode yang digunakan dalam pengembangan perangkat terdiri atas analisis kebutuhan, desain, pengembangan dan evaluasi unjuk kinerja perangkat. Analisis kebutuhan digunakan untuk mengumpulkan informasi dan literatur terkait analisis tujuan, penyelesaian masalah dan produk dari pengembangan perangkat. Desain bertujuan untuk menghasilkan spesifikasi perangkat untuk selanjutnya: (1) mengidentifikasi komponen elektronika yang dibutuhkan; (2) merancang diagram blok perangkat; (3) merancang kebutuhan software; dan (4) merancang kinerja perangkat. Pengembangan dilakukan sebagai tahap implementasi hasil desain yang terdiri atas: (1) merakit perangkat dari sisi hardware; (2) melakukan pemrograman perangkat; (3) melakukan pengemasan (packaging) perangkat; dan (4) membuat manual book perangkat. Tahapan evaluasi adalah melakukan evaluasi unjuk kinerja perangkat. Uji kinerja dilakukan dengan menguji beberapa parameter pengukuran elektronika dan uji fungsionalitas perangkat kepada ahli. Langkah selanjutnya adalah melakukan perbaikan-perbaikan yang diperlukan sebagai hasil evaluasi.

\section{HASIL DAN PEMBAHASAN}

Pengembangan diawali dengan menganalisis keadaan sebelum pengembangan dan menemukan gap permasalahan yang ingin diselesaikan melalui pengembangan khususnya terkait jenis CCTV, pengelolaan dan penggunaan. Analisis tersebut dilakukan untuk mempermudah tahapan analisis kebutuhan. Solusi diperoleh melalui analisis kajian. Tabel 1 menggambarkan penggunaan CCTV dikelas sebelum pengembangan dan CCTV dikelas yang dikembangkan penulis.

Tabel 1. Penggunaan CCTV dikelas

\begin{tabular}{|c|c|c|}
\hline Aspek & Sebelum pengembangan & Pengembangan \\
\hline 1. Jenis CCTV & Statis & Statis yang direkayasa agar mampu bergerak dinamis \\
\hline 2. Pengelolaan & $\begin{array}{l}\text { Admin mengakses perekaman } \\
\text { melalui server lokal }\end{array}$ & $\begin{array}{l}\text { a. Admin mengakses perekaman melalui server lokal } \\
\text { b. Dosen mengakses perekaman melalui akun } \\
\text { YouTube dosen (dapat link dengan Besmart) sesuai } \\
\text { waktu pelaksanaan mata kuliah yang diampu }\end{array}$ \\
\hline 3. Penggunaan & $\begin{array}{l}\text { a. Penghapusan data perekaman } \\
\text { setelah } 3 \text { hari operasional } \\
\text { oleh admin }{ }^{(23)} \text {. } \\
\text { b. Data perekaman digunakan } \\
\text { admin untuk mengecek } \\
\text { apabila terjadi laporan } \\
\text { kehilangan barang }\end{array}$ & $\begin{array}{l}\text { a. Admin dapat mengakses data perekaman dengan } \\
\text { prosedur dan fungsi seperti sebelum pengembangan } \\
\text { b. Dosen menyimpan data perekaman diakun YouTube } \\
\text { dosen (hanya mata kuliah yang diampu), sehingga } \\
\text { dapat diputar berulang-ulang bahkan disimpan. } \\
\text { Dosen dapat menggunakan CCTV dikelas untuk } \\
\text { aktivitas pembelajaran, misalnya: pengawasan jarak } \\
\text { jauh diluar jangkauan intranet UNY, bahan } \\
\text { pembelajaran dan menilai aktivitas belajar siswa, } \\
\text { baik real time maupun tidak real time. }\end{array}$ \\
\hline
\end{tabular}


CCTV di kelas FT UNY berupa CCTV statis yang terpasang di sembilan kelas gedung RF dan di satu kelas laboratorium PTBB ${ }^{(23)}$. Pengelolaan data perekaman dilakukan oleh dua admin yang bertugas dibawah koordinasi Kasubag UKP FT UNY. Hasil wawancara dengan admin diantaranya adalah (1) Proses perekaman menggunakan PC Unit dengan software bawaan ip cam yang diakses pada server lokal UNY; (2) penyimpanan data perekamana dilakukan sekitar 3 sampai dengan 5 hari, setelah itu dilakukan penghapusan data dikarenakan kapasitas penyimpanan data yang terbatas; (3) selama ini tidak digunakan dalam pembelajaran tetapi untuk pengawasan/ keamanan. CCTV statis mengakibatkan proses perekaman data tidak dapat secara menyeluruh menangkap aktivitas belajar di kelas. Akses terbatas oleh admin melalui server lokal dapat menyulitkan bagi dosen yang ingin memantau aktivitas belajar dari jarak jauh dan tidak berada di area jangkauan server lokal (intranet UNY). Tambahan, penghapusan data perekaman menjadi permasalahan tersen diri apabila suatu ketika dosen ingin menggunakan kembali data perekaman baik sebagai bukti pemantauan, bahan pembelajaran di kelas maupun untuk menilai aktivitas belajar mahasiswa. Ilustrasi pengelolaan CCTV dikelas sebelum pengembangan dapat dilihat pada Gambar 5.
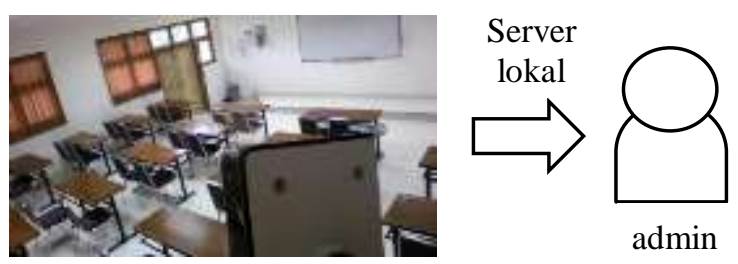

CCTV statis di kelas

Gambar 5. Pengelolaan CCTV statis oleh Admin melalui servel lokal

Melalui analisis kajian, ditemukan beberapa solusi, yaitu terkait pemanfaatan CCTV statis yang sudah ada terebut perlu direkayasa agar mampu bergerak dinamis memanfaatkan motor servo sebagai penggerak dan Raspberry Pi 3 sebagai pengendali gerakan. Pengelolaan CCTV di kelas dimaksudkan oleh penulis agar admin tetap memiliki wewenang mengakses perekaman melalui server lokal dan dosen dapat mengakses perekaman melalui akun YouTube dosen sesuai waktu pelaksanaan mata kuliah yang diampu. Akses tersebut juga dapat dipadukan dengan memanfaatkan fitur Besmart sebagai salah satu media pembelajaran daring di UNY. Dengan demikian CCTV di kelas dapat dimaksimalkan dalam pembelajaran khususnya untuk pengawasan jarak jauh diluar jangkauan intranet UNY, bahan pembelajaran dan menilai aktivitas belajar siswa. Hal tersebut mendukung pembelajaran abad 21 dalam pembelajaran dan upaya menyongsong revolusi industry 4.0 yaitu menghadirkan teknologi. Ilustrasi pengelolaan perangkat yang dikembangkan penulis dapat dilihat pada Gambar 6.

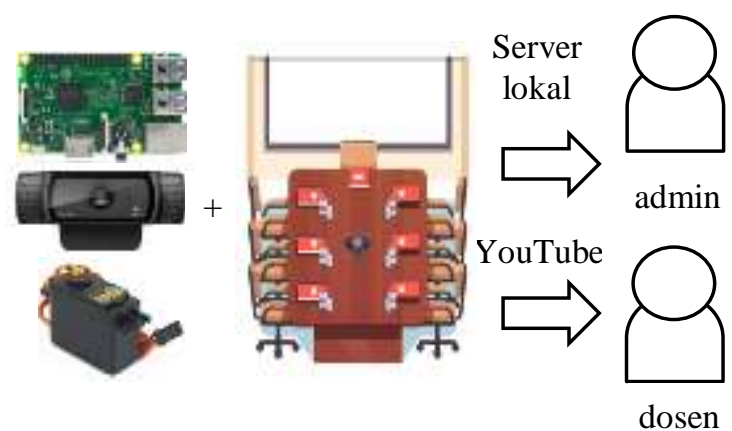

CCTV dinamis di kelas ${ }^{(19 ; 24 ; 25 ; 26)}$

dosen

Gambar 6. Pengeloalaan CCTV dinamis oleh Admin melalui servel lokal dan oleh Dosen melalui akun YouTube

Secara umum, signifikansi sebelum pengembangan dan pengembangan adalah terkait CCTV dinamis dan akses data perekaman oleh Dosen melalui akun Youtube dosen. Kedua hal tersebut menjadi dasar untuk melakukan analisis kebutuhan. Analisis terkait aspek tujuan, penyelesaian masalah dan aspek produk yang dikembangkan. Analisis tersebut berdasarkan kajian dari beberapa sumber. Hasil analisis aspek tujuan dan produk tersaji pada Tabel 2. 
Tabel 2. Hasil analisis aspek tujuan dan produk

\begin{tabular}{|c|c|}
\hline Aspek & Analisis \\
\hline Tujuan & $\begin{array}{l}\text { - mengobservasi prosedur pembelajaran } \\
\text { di kelas tanpa mengganggu kegiatan } \\
\text { kelas }{ }^{(1)} \\
\text { - memantau para peserta didik dan } \\
\text { refleksi pengelolaan pembelajaran } \\
\text { kelas oleh pendidik }{ }^{(2)} \\
\text { - menilai keefektifan pendidik pada } \\
\text { pembelajaran di kelas }{ }^{(3 ; 4)} \\
\text { - mengobservasi pembelajaran dikelas } \\
\text { jarak jauh }{ }^{(5)} \\
\text { - mengawasi pelaksanaan ujian }{ }^{(6 ; 7 ; 8)} \\
\text { - aktualisasi peran pendidik melalui } \\
\text { implementasi pembelajaran di abad } 21 \\
\text { yaitu penerapan digital literacy skills } \\
\text { (21) dan langkah strategis menghadapi } \\
\text { Revolusi Industri 4.0 yaitu } \\
\text { pembelajaran inovatif dengan sistem } \\
\text { distance learning }{ }^{(22)}\end{array}$ \\
\hline $\begin{array}{l}\text { Penye- } \\
\text { lesaian } \\
\text { masalah }\end{array}$ & $\begin{array}{l}\text { - (1) keterbatasan gerak CCTV diatasi } \\
\text { dengan penambahan motor; (2) } \\
\text { keterbatasan akses data perekaman } \\
\text { video diatasi dengan pengiriman real } \\
\text { time melalui akun YouTube; dan (3) } \\
\text { pengendali sistem kinerja perangkat } \\
\text { menggunakan Raspberry Pi } 3\end{array}$ \\
\hline Produk & $\begin{array}{l}\text { - integrasi Raspberry sebagai pemroses } \\
\text { gerak motor pada kamera sekaligus } \\
\text { mengunggah data ke YouTube }\end{array}$ \\
\hline
\end{tabular}

Hasil analisis pada Tabel 2 selanjutnya menjadi dasar pada tahapan desain. Secara umum spesifikasi perangkat dari perangkat Video Moving Surveillance yang Terintegrasi YouTube menggunakan Raspberry $\mathrm{Pi} 3$ berupa: (1) perangkat hardware terdiri atas Raspberry Pi 3 B, Webcam dan Servo; dan (2) manual book perangkat berisi spesifikasi, cara penggunaan dan cara perawatan. Secara umum kebutuhan perangkat keras berupa Raspberry Pi 3 B, Webcam Logitech C920, Servo MG995, Power Supply 5V/3A - Micro USB, Wireless Keyboard \& Mouse Logitech MK215, Aluminium Heatsink, Mini Fan dan Raspberry Box. Kebutuhan perangkat lunak terdiri atas FFMPEG dan bahasa pemrograman phyton. Komponen elektronika yang dibutuhkan dalam pengembangan perangkat tersebut secara lengkap tersaji pada Tabel 3.

Tabel 3. Identifikasi kebutuhan perangkat

\begin{tabular}{|c|c|c|}
\hline Komponen & Fungsi & Keunggulan \\
\hline 1. Raspberry Pi 3 B & $\begin{array}{l}\text { Controller \& } \\
\text { Processing Unit }\end{array}$ & $\begin{array}{l}\text { - Memiliki fasilitas yang lengkap (Wi-Fi, Bluetooth) } \\
\text { - Mudah dalam pengoperasian } \\
\text { - Sistem operasi freeware (Raspbian OS) }\end{array}$ \\
\hline $\begin{array}{l}\text { 2. Webcam Logitech } \\
\text { C920 }\end{array}$ & $\begin{array}{l}\text { Input (Video } \\
\text { Recorder) }\end{array}$ & $\begin{array}{l}\text { - Memiliki resolusi pengambilan video hingga Full HD (1080P) } \\
\text { - Kualitas rekaman yang baik }\end{array}$ \\
\hline 3. Servo MG995 & $\begin{array}{l}\text { Output } \\
\text { (Penggerak } \\
\text { Webcam) }\end{array}$ & $\begin{array}{l}\text { - Memiliki fasilitas yang lengkap } \\
\text { - Memilik torsi yang besar mencapai } 11 \mathrm{Kg} / \mathrm{cm} \\
\text { - Tegangan kerja rendah }(4.8-6 \text { Volt }) \\
\text { - Menggunakan gear yang terbuat dari logam }\end{array}$ \\
\hline $\begin{array}{l}\text { 4. Power Supply } \\
\text { 5V/3A Micro USB }\end{array}$ & Catu Daya & $\begin{array}{l}\text { - Memiliki tegangan output stabil } 5 \text { Volt } \\
\text { - Kemampuan arus mencapai } 3 \text { Ampere }\end{array}$ \\
\hline $\begin{array}{l}\text { 5. Wireless Keyboard } \\
\text { \& Mouse Logitech } \\
\text { MK215 }\end{array}$ & $\begin{array}{l}\text { Input } \\
\text { (Command) }\end{array}$ & $\begin{array}{l}\text { - Tanpa menggunakan kabel } \\
\text { - Single Receiver, menghemat Port USB } \\
\text { - Auto off, menghemat energi }\end{array}$ \\
\hline $\begin{array}{l}\text { 6. Aluminium } \\
\text { Heatsink } \\
\text { 7. Mini Fan }\end{array}$ & $\begin{array}{l}\text { Pendingin CPU } \\
\text { pada Raspberry }\end{array}$ & $\begin{array}{l}\text { - Terbuat dari bahan yang mudah menghantarkan panas } \\
\text { - Bentuk yang efektif dalam membuang panas } \\
\text { - Dapat bekerja pada tegangan } 5 \text { Volt }\end{array}$ \\
\hline 8. Raspberry Box & $\begin{array}{l}\text { Melindungi } \\
\text { Raspberry }\end{array}$ & $\begin{array}{l}\text { - Terbuat dari bahan plastik ABS yang kuat } \\
\text { - Bentuk presisi sesuai dengan board Raspberry }\end{array}$ \\
\hline
\end{tabular}

Langkah desain selanjutnya adalah merancang diagram blok perangkat. Webcam memberikan input berupa video perekaman dan diteruskan ke pengendali Raspberry Pi 3 model B. Output dari pengendali adalah: (1) servo yang memberi pergerakan webcam dan (2) akses pengiriman data secara online ke YouTube. Blok diagram perangkat seperti pada Gambar 7.

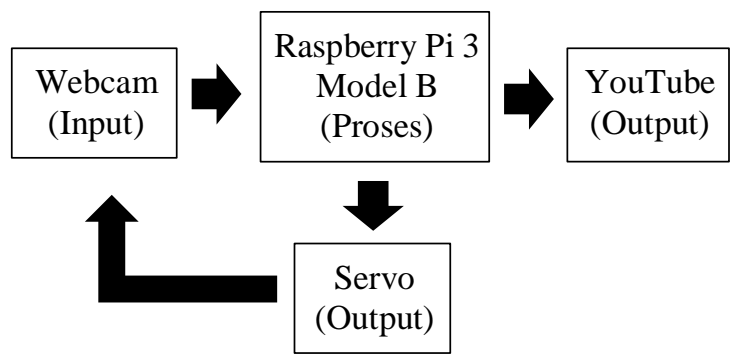

Gambar 7. Blok diagram 
Software yang dibutuhkan dalam perangkat adalah terkait pemrograman pada bagian pemroses, yaitu Raspberry $\mathrm{Pi} 3$. Pemrograman menggunakan FFMPEG dan bahasa pemrograman phyton. FFMPEG merupakan aplikasi berbasis command line yang mampu melakukan konversi, encoding, decoding dan memanipulasi format video di beberapa platform sistem operasi seperti Linux, Windows dan Mac. Aplikasi tersebut dipilih karena memiliki kesesuaian dengan Raspberry Pi 3. Untuk mengetahui rancangan kerja perangkat, dapat dilihat pada Gambar 8 .

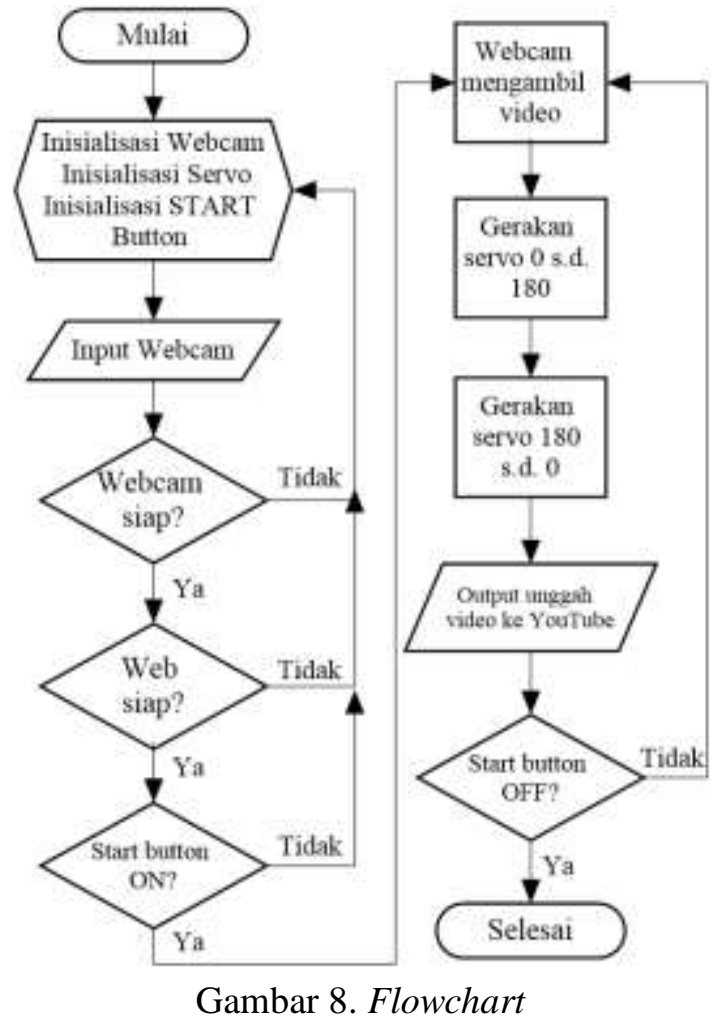

Perangkat bekerja diawali dengan proses inisialisasi webcam, servo dan start button, kemudian mengambil input webcam. Ketika webcam siap, servo siap dan start button ON, maka proses perekaman video secara bergerak ke kanan dan ke kiri sebesar $180^{\circ}$ akan dilakukan. Output dari perekaman adalah proses pengunggahan video ke YouTube. Apabila start button OFF maka proses selesai. Untuk skema rangkaian tersaji pada Gambar 9 dan desain packaging tersaji pada Gambar 10.

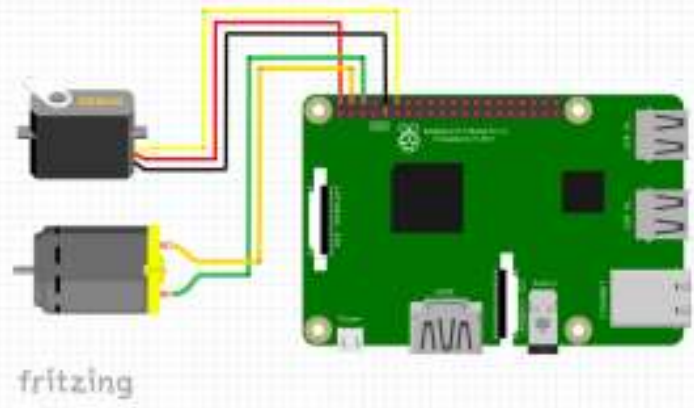

Gambar 9. Skema rangkaian

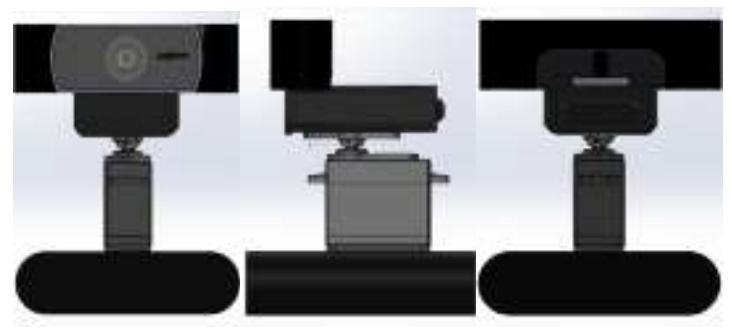

Gambar 10. Desain packaging (tampak depan, samping dan belakang)

Flowchart, skema rangkaian dan desain packaging selanjutnya diimplementasikan pada tahapan pengembangan. Salah satu tahapan pengembangan yaitu pemrograman, khususnya untuk memprogram pergerakan servo, memantau temperature perangkat dan pengiriman data ke YouTube. Berikut ini cuplikan source code dari pemrograman yang dilakukan.

Pergerakan servo:

while True:

$$
\begin{gathered}
\text { for pulse in range }(50,200,1) \text { : } \\
\text { wiringpi.pwmWrite }(18, \text { pulse) } \\
\text { time.sleep(delay_period) } \\
\text { for pulse in range(200,50,-1): } \\
\text { wiringpi.pwmWrite(18, pulse) } \\
\text { time.sleep(delay_period) }
\end{gathered}
$$

Monitor temperature:

while True:

$$
\begin{aligned}
& \text { print (measure_temp }()) \\
& \text { time. } \operatorname{sleep}(0.5)
\end{aligned}
$$

Pengunggahan data ke YouTube

ffmpeg -ar 24000 -ac 2 -f alsa -i hw:1,0 -f v412 -codec:v h264 -framerate 10 -video_size $640 \times 360$-itsoffset 0.5 -i / dev/video0 -copyinkf - codec: $v$ copy - codec: a aac - ab 50k - g 1 -f flv rtmp://x.rtmp.youtube.com/live2/tzxb-6681-jy1xakwu 


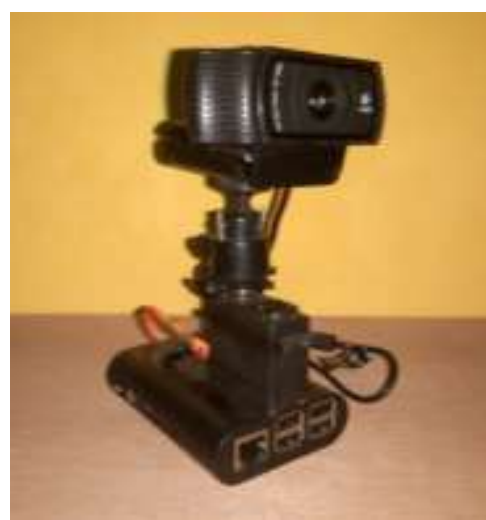

Gambar 11. Perangkat Video Moving

Surveillance yang Terintegrasi YouTube menggunakan Raspberry Pi 3

Gambar 11 merupakan perangkat Video Moving Surveillance yang Terintegrasi YouTube menggunakan Raspberry Pi 3. Setelah perangkat selesai dikembangkan, dilakukan dua uji, yaitu uji beberapa parameter pengukuran elektronika dan uji fungsionalitas perangkat kepada ahli. Tabel 4 menunjukkan hasil uji beberapa parameter pengukuran elektronika yang dilakukan.

Tabel 4. Hasil uji beberapa parameter pengukuran elektronika

\begin{tabular}{llll}
\hline No & \multicolumn{1}{c}{ Parameter } & $\begin{array}{l}\text { Kondisi } \\
\text { standby }\end{array}$ & $\begin{array}{l}\text { Kondisi } \\
\text { running }\end{array}$ \\
\hline 1 & Raspberry Pi 3 & & \\
& - Tegangan & $5.12 \mathrm{~V}$ & $5.07 \mathrm{~V}$ \\
& - Arus & $0.506 \mathrm{~A}$ & $1.122 \mathrm{~A}$ \\
& - Tegangan Fan & $4.99 \mathrm{~V}$ & $4.84 \mathrm{~V}$ \\
& & \\
(pendingin) & & \\
Servo & & \\
& - Tegangan & $4.99 \mathrm{~V}$ & $4.84 \mathrm{~V}$ \\
& - Arus & $0.285 \mathrm{~A}$ & $0.285 \mathrm{~A}$ \\
& - PWM Voltage & $0 \mathrm{mV}$ & $105.7 \mathrm{mV}$ \\
& - PWM Frequency & $0 \mathrm{~Hz}$ & $35.54 \mathrm{~Hz}$ \\
- Duty Cycle & $0 \%$ & $3.2 \%$ \\
\hline
\end{tabular}

Secara umum hasil pengujian parameter elektronika tersebut menunjukkan hasil yang baik dan terbukti perangkat dapat melakukan unjuk kinerja yang sesuai dengan rancangan. Data tersebut adala data setelah melakukan perbaikan perangkat hardware. Sebelumnya perangkat sempat bermasalah dikarenakan perangkat mengalami overheat (suhu berada di kisaran $80^{\circ} \mathrm{C}$ ). Overheat ditandai dengan munculnya indikator overheat. Overheat ini yang mengakibatkan perangkat tidak dapat bekerja dengan sesuai. Permasalahan tersebut diatasi dengan menambahkan fan pendingin dan setelah diterapkan, rerata suhu perangkat pada range $40^{\circ}$ sampai dengan $45^{\circ}$. Suhu tersebut menghasilkan kinerja sesuai rancangan. Terkait adanya penurunan tegangan antara kondisi standby dan kondisi running. Penurunan tegangan terjadi karena pada saat standby Raspberry lebih sedikit mengkonsumsi daya, sedangkan saat running Raspberry lebih banyak mengkonsumsi daya. Oleh karena itu pada saat running, tegangan pada servo menurun. Selanjutnya dilakukan hasil pengujian delay penampilan video di YouTube seperti pada Tabel 5.

Tabel 5. Delay

\begin{tabular}{lll}
\hline No. & Menit ke- & Delay \\
\hline 1 & $7: 30$ & $23,53 \mathrm{~s}$ \\
2 & $10: 50$ & $22,64 \mathrm{~s}$ \\
3 & $13: 50$ & $22,50 \mathrm{~s}$ \\
\hline
\end{tabular}

Antara aktivitas sesungguhnya dengan data video yang dapat diakses pada YouTube mengalami delay rata-rata 22,89s. Dengan delay tersebut, perangkat dapat berfungsi sesuai harapan. Kualitas gambar yang dihasilkan di YouTube cukup baik tergantung GPU dan display dari perangkat yang digunakan untuk mengakses YouTube. Gambar 12 menunjukkan hasil pengunggahan perekaman video dikelas.

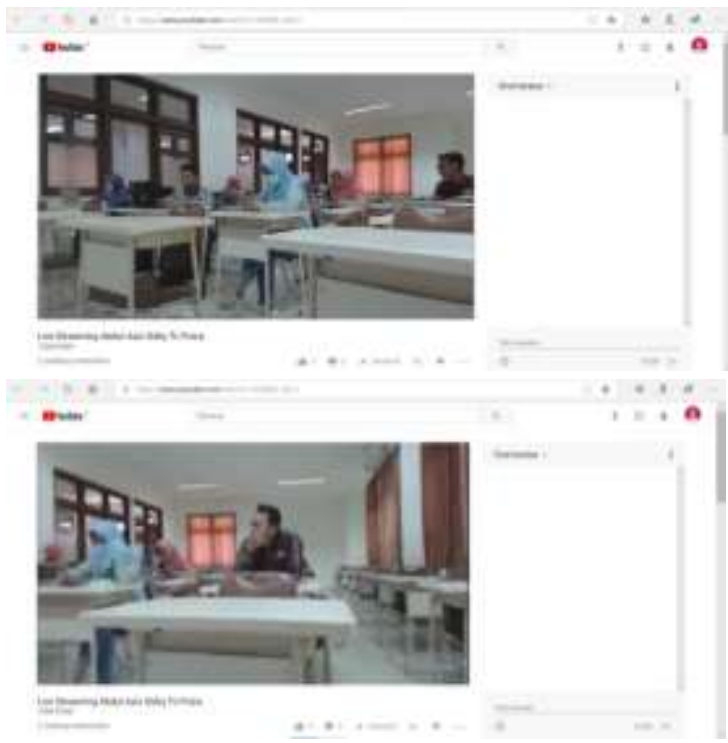

Gambar 12. Hasil perekaman video (dinamis) yang diakses pada Youtube 
Setelah pengukuran elektronika menunjukkan hasil yang sesuai dan aman secara kinerja, maka selanjutnya dilakukan uji fungsionalitas. Data uji fungsionalitas tersaji pada Tabel 6.

Tabel 6. Hasil uji fungsionalitas perangkat (B: Berhasil dan TB: Tidak Berhasil)

\begin{tabular}{|c|c|c|}
\hline $\begin{array}{l}\text { No. } \\
1\end{array}$ & $\begin{array}{l}\text { Pernyataan } \\
\text { Ketika start button posisi ON, maka } \\
\text { kamera merekam bergerak ke kanan } \\
\text { dan kiri } 180^{\circ} \text { serta mengunggah ke } \\
\text { akun YouTube }\end{array}$ & $\sqrt{ }^{\mathrm{B} B}$ \\
\hline 2 & $\begin{array}{l}\text { Pergerakan servo sebesar } 180^{\circ} \text { ke } \\
\text { kanan dan ke kiri }\end{array}$ & $\sqrt{ }$ \\
\hline 3 & $\begin{array}{l}\text { Pergerakan servo stabil, sehingga } \\
\text { video yang terekam terlihat jelas }\end{array}$ & $\sqrt{ }$ \\
\hline 4 & $\begin{array}{l}\text { Delay video di YouTube dengan } \\
\text { keadaan sebenarnya dibawah } 60 \text { s }\end{array}$ & $\sqrt{ }$ \\
\hline 5 & Kualitas video di YouTube jelas & $\sqrt{ }$ \\
\hline 6 & $\begin{array}{l}\text { Video dapat diunduh dengan } \\
\text { kualitas yang bagus }\end{array}$ & $\sqrt{ }$ \\
\hline 7 & $\begin{array}{l}\text { Suhu perangkat pemroses dibawah } \\
50^{\circ} \text { dan perangkat memiliki kinerja } \\
\text { sesuai harapan }\end{array}$ & $\sqrt{ }$ \\
\hline 8 & $\begin{array}{l}\text { Admin dapat mengakses data } \\
\text { perekaman dengan prosedur dan } \\
\text { fungsi seperti } \\
\text { pengembangan }\end{array}$ & $\sqrt{ }$ \\
\hline 9 & $\begin{array}{l}\text { Dosen mengakses perekaman } \\
\text { melalui akun YouTube dosen } \\
\text { (dapat link dengan Besmart) sesuai } \\
\text { waktu pelaksanaan mata kuliah } \\
\text { yang diampu }\end{array}$ & $\sqrt{ }$ \\
\hline \multirow[t]{8}{*}{10} & $\begin{array}{l}\text { Perangkat secara umum dapat } \\
\text { digunakan untuk: }\end{array}$ & \\
\hline & $\begin{array}{l}\text { a. mengecek kejadian luar biasa } \\
\text { seperti laporan kehilangan barang }\end{array}$ & $\sqrt{ }$ \\
\hline & $\begin{array}{l}\text { b. mengobservasi } \\
\text { pembelajaran di kelas tanpa } \\
\text { mengganggu kegiatan kelas }\end{array}$ & $\sqrt{ }$ \\
\hline & $\begin{array}{l}\text { c. memantau para peserta didik dan } \\
\text { refleksi pengelolaan } \\
\text { pembelajaran kelas oleh pendidik }\end{array}$ & $\sqrt{ }$ \\
\hline & $\begin{array}{l}\text { d. menilai keefektifan pendidik pada } \\
\text { pembelajaran di kelas }\end{array}$ & $\sqrt{ }$ \\
\hline & $\begin{array}{l}\text { e. mengobservasi pembelajaran } \\
\text { dikelas jarak jauh }\end{array}$ & $\sqrt{ }$ \\
\hline & f. megnawasi pelaksanaan ujian & $\sqrt{ }$ \\
\hline & $\begin{array}{l}\text { g. aktualisasi peran pendidik } \\
\text { melalui implementasi } \\
\text { pembelajaran di abad } 21 \text { (digital } \\
\text { literacy skills) dan menghadapi } \\
\text { Revolusi Industri } 4.0 \text { yaitu } \\
\text { pembelajaran inovatif (sistem } \\
\text { distance learning) }\end{array}$ & $\sqrt{ }$ \\
\hline
\end{tabular}

Terlihat dari Tabel 6 bahwa uji fungsionalitas berhasil sesuai yang direncanakan. Perangkat dapat memberikan unjuk kinerja dengan fungsi yang baik.
Terdapat beberapa saran dari para ahli yang menilai uji fungsionalitas perangkat, diantaranya adalah: (1) perlu memperhatikan posisi pemasangan perangkat yang dapat menjangkau keseluruhan aktivitas belajar, misalnya saja dipasang ditengah ruangan pada posisi diatas; dan (2) perlu mengintegrasikan tracking detection dan object recognition terhadap aktivitas belajar peserta didik. Saran dari para ahli tersebut untuk poin pertama ditindalanjuti, sedangkan untuk poin kedua akan ditindaklanjuti pada penelitian selanjutnya.

\section{SIMPULAN}

Analisis menunjukkan bahwa: (1) keterbatasan gerak CCTV diatasi dengan penambahan motor; (2) keterbatasan akses data perekaman video diatasi dengan pengiriman secara real time dengan memanfaatkan YouTube; dan (3) pengendali sistem kinerja perangkat menggunakan Raspberry Pi 3 model B. Hasil evaluasi menunjukkan bahwa semua parameter pengukuran elektronika sesuai dengan target keberhasilan dan uji fungsionalitas menunjukkan bahwa perangkat dapat berfungsi untuk merekam aktivitas pembelajaran di kelas yang dapat dipantau secara real time melalui YouTube dengan kualitas yang baik (rata-rata delay sebesar $22,89 \mathrm{~s}$ ). Hasil pengembangan perangkat ini diharapkan dapat menjadi alternatif pemanfaatan teknologi dalam pembelajaran khususnya dalam pengawasan dan penilaian aktivitas belajar siswa yang mendukung pembelajaran abad 21 dan menghadapi Revolusi Industri 4.0.

\section{REFERENSI}

[1] Chabe, A.M. An experiment with CCTV in teacher education. 1962, Peabody Journal of Education, 40(1), 24-30.

[2] SR, Suryavanshi \& LJ, Sankpal. Monitor Student's Presence in Classroom. 2016, Journal of Information Technology \& Software Engineering, 6(4). 
[3] Strong, M., Gargani, J. \& Hacifazlioglu, O. Do We Know a Successful Teacher When We See One? Experiments in the Identification of Effective Teachers. 2011, Journal of Teacher Education, 62(4), 367382.

[4] Cartmell, A.E. The use of cctv in the assessment of teacher effectiveness. 1971, Programmed Learning and Educational Technology, 8(3), 173-185.

[5] Using Videoconferencing Technology to Enhance Classroom Observation Methodology for the Instruction of Preservice Early Childhood Professionals. Pickering, L.E. \& Walsh, E.J. 2011, Journal of Digital Learning in Teacher Education, 27(3), 99-108.

[6] Kurnia, D. \& Putri, W.D. Pengawasan UNBK Lewat CCTV Dirasa Mampu Tingkatkan Kejujuran. [Online] 2018. https://www.republika.co.id/berita/nasional/ umum/18/04/02/p6k4p1359-pengawasanunbk-lewat-cctv-dirasa-mampu-tingkatkankejujuran.

[7] Fajar, A. UNBK dengan CCTV Dinilai Meningkatkan Integritas Siswa. [Online] 2018. https://www.idntimes.com/news/indo nesia/ardiansyah-fajar/unbk-dengan-cctvdinilai-meningkatkan-integritas-siswa/full.

[8] Dadan. SMAN 3 Awasi UNBK dengan CCTV. [Online] 2018. http://poskotanews. com/2018/04/09/sman-3-awasi-unbkdengan-cctv/.

[9] Statista. Global active usage penetration of leading social networks as of February 2017. [Online] Juni 2017. https://www. statista.com/statistics/274773/globalpenetration-of-selected-social-media-sites/.

[10] Snelson, C. YouTube across the Disciplines: A Review of the Literature. 2011, MERLOT Journal of Online Learning and Teaching, 7(1), 159-169.

[11] Siant, J. Tahukah Anda: Youtube itu Lebih Populer dari Wikipedia? Kenapa? [Online] 2015. https://portal-uang.com/2015/12/tahu kah-anda-youtube-itu-lebih-populer-dariwikipedia-kenapa.html.

[12] Sherer, P. \& Shea, T.Using Online Video to Support Student Learning and Engagement. 2011, COLLEGE TEACHING, 59, 56-59.

[13] Tan, E. Informal learning on YouTube: exploring digital literacy in independent online learning. 2013, Learning, Media and Technology, 38(4), 463-477.

[14] Jones, T \& Cuthrell, K. YouTube: Educational Potentials and Pitfalls. 2011, Computers in the Schools, 28, 75-85.
[15] Bergmann, J \& Sams, A. Flip your classroom: rich every student in every class every day. 1st edition. Washingtin DC: International Society for Technology in Education, 2012.

[16] Little, C. The flipped classroom in further education: literature review and case study. 2015, Research in Post-Compulsory Education, 20(3), 265-279.

[17] Kellner, D. \& Kim, G. YouTube, Critical Pedagogy, and Media Activism. 2010, Review of Education, Pedagogy, and Cultural Studies, 32(1), 3-36.

[18] The MathWorks, Inc. Read temperature from a TMP102 sensor. s.1. : diambil dari https://www.mathworks.com/help/supportp $\mathrm{kg} /$ raspberrypi/examples/read-temperaturefrom-a-tmp102-sensor.html.

[19] RaspberryPi. Raspberry Pi 3 Model B: Technical Specification. s.l.: dari https://cdn.sparkfun.com/datasheets/Dev/Ra spberryPi/2020826.pdf.

[20] Farnell dan Newark. Raspberry Pi 3 Model B: Technical Specification. s.l. : diambil dari https://www.terraelectronica.ru/pdf/sho w?pdf_file $=\% 252 \mathrm{Fds} \% 252 \mathrm{Fpdf} \% 252 \mathrm{FT} \%$ 252FTechicRP3.pdf.

[21] Trilling, B. \& Fadel, C. 21st century skills: learning for life in our times. San Francis co: Jossey-Bass A Wiley Imprint, 2009.

[22] Biro Kerjasama dan Komunikasi Publik. SIARAN PERS Nomor : 04/SP/HM/BK KP/I/2018, Pengembangan Iptek dan Pendidikan Tinggi di Era Revolusi Industri 4.0. [Online] 2018. https://www.ristekdikti. go.id/pengembangan-iptek-dan-pendidikantinggi-di-era-revolusi-industri-4-0/\#p7SdqU tlMGvCp83L.99.

[23] Hardiantoro, T \& Fathonah, S. (wawancara) penggunaan CCTV di kelas Fakultas Teknik UNY. [Online] 2018. [Dikutip: 12 April 2018.]

[24] Ansaldo, M. Logitech HD Pro Webcam C920 review: HD video and stereo sound add polish to video calls. [Online] 2017. https://www.pcworld.com/article/3124933/ consumer-electronics/logitech-hd-prowebcam-c920-review-hd-video-and-stereosound-add-polish-to-video-calls.html.

[25] Assoc. \& Jones, M.P. 31150-MP MG995 High Speed Servo Actuator. [Online] https: //www.mpja.com/download/31150mp.pdf.

[26] Freepik, iconicbestiary/. Empty conference board room Free Vector. [Online] https://www.freepik.com/free-vector/empty -conference-board-room_1311351.htm\#ter $\mathrm{m}=$ classroom icon\&page $=1 \&$ position $=32$. 